\title{
Effects of Sea Buckthorn and Boswellia Extracts in Inflammatory Orofacial Pain by Xerostomia in Rats
}

\author{
Ja-Hyeong Choi ${ }^{1, *}$, Tae-Heon Kim ${ }^{2, *}$ and Min-Kyung Lee (3,;** $^{3, *}$ \\ ${ }^{I}$ Department of Dental Hygiene, Ulsan College, Ulsan 44610, Korea \\ ${ }^{2}$ Department of Dental Hygiene, Taegu Science University, Daegu 41453, Korea \\ ${ }^{3}$ Department of Dental Hygiene, Dong Eui University, Busan 47340, Korea
}

\begin{abstract}
Xerostomia due to the subjective dry mouth feeling that may occur even when the salivary gland function reduction is not objectively confirmed. The purpose of this study was to investigate whether or not dry mouth is more sensitive to pain in the oral facial area, which is the main cause of dental problems. The natural products used in this study are Boswellia serrata and seabuckthorn, Both natural substances are known as a representative antioxidant substance rich in vitamins. 4-DAMP was injected into the peritoneal cavity of the experimental animals, and 5\% formalin was injected into the face to observe the change of inflammatory pain. Boswellia $(15,30 \mathrm{mg} / \mathrm{kg})$ or seabuckthorn $(150,30 \mathrm{mg} / \mathrm{kg}, 5 \mathrm{mg} / \mathrm{kg}) \mathrm{after}$ formalin infusion, As a result, pain response was significantly reduced in the drug-infused group compared to the formalininfused group $(* P<0.05)$. It was also found that the two drugs were more effective when administered together. Based on these results, we confirm that natural extract can be an alternative treatment modality for the control of oral facial inflammatory pain.
\end{abstract}

Key Words: Xerostomia, Boswellia serrata, Sea buckthorn, Orofacial pain

\section{서 론}

구강건조증은 객관적 혹은 주관적으로 호소하는 구강 내 입마름증으로, 타액선 기능의 감소에 의한 타액량 부 족 또는 타액선 기능 감소를 동반하지 않는 상태에서도 발생할 수 있는 구강질환이다(Napenas et al., 2009). 구강건 조는 구강 내 통증 및 저작 장애 등을 포함한 조직의 감 염 및 병변 등의 다양한 문제를 야기하는 구강 증상 중 하나이며, 최근에는 노인층을 비롯한 성인의 발병률이 증 가하고 있는 주요한 구강병으로 여겨진다. 구강건조증을 유발하는 다양한 원인으로는 노화로 인한 세포 기능 저
하 및 세포 수 감소, 근 수축 기능 감소(Yasuko et al., 1998) 와 같은 퇴행성 변화 등과 함께 자율신경계 기능 저하에 따른 생리적 원인뿐만 아니라 불안감이나 스트레스와 같 은 심리적인 요인도 배제할 수 없다(Jang et al., 2006). 또한 고령화 사회로 인하여 전신질환 환자의 증가로 고혈압제 재나 삼환성 항우울제의 복용, 타액선 질환, 방사선치료 등이 원인이 될 수 있으며 현저하게 타액선 기능 감소가 증상으로 나타날 경우에는 양대 구강질환인 치아우식증과 치주질환을 비롯하여 구강 캔디다증, 미각변화, 구취 등 의 구강질환이 동반되어 나타날 수 있다(Kim et al., 2011). 또한 구강건조증이 발생하면 구강 기능이 제한되고 저작 및 연하능력이 감소하여 소화불량 등의 전신적 증상으로

Received: May 2, 2019 / Revised: June 17, 2019 / Accepted: June 17, 2019

*Professor

${ }^{\dagger}$ Corresponding author: Min-Kyung Lee. Department of Biomedical Health Science, Dong Eui University, 176 Eongwangno (Gayadong san24), Busanjin-gu, Busan 47340, Korea.

Tel: +82-51-890-4238, Fax: +82-0505-182-6878, e-mail: lmk849@deu.ac.kr

(C)The Korean Society for Biomedical Laboratory Sciences. All rights reserved.

@ This is an Open Access article distributed under the terms of the Creative Commons Attribution Non-Commercial License (http://creativecommons.org/licenses/by-nc/3.0/) which permits unrestricted non-commercial use, distribution, and reproduction in any medium, provided the original work is properly cited. 
이어지기도 하며 신체적, 사회적 및 심리적 안녕에도 심 각한 영향을 줄 수 있다(Gerdin et al., 2005; Thomson et al., 2006). 이러한 구강건조증의 치료를 위하여 미국 식품의 약국(FDA)의 승인을 받은 약물인 필로카르핀(Pilocarpine) 과 세비멜린(Cevimeline)이 대표적인 타액 분비 촉진제로 써 주로 처방되고 있다. 필로카르핀은 무스카린 수용체 (Muscarinic receptor, M)에 작용하여 부교감신경을 자극하 고, 세비멜린은 무스카린 수용체 중 $\mathrm{M} 3$ 와 높은 결합력 을 나타내는 타액선 자극제로 알려져 있다(Choi and Lim, 2016). 필로카르핀은 $5 \mathrm{mg}$, 세비멜린의 경우 $30 \mathrm{mg}$ 을 각각 하루 세 번 복용하는 것이 일반적이며, 투약기간은 최소 3 개월 이상 복용하는 것을 권장한다(Braga et al., 2009). 두 약물은 구강건조증 개선을 위한 긍정적인 효능이 우수한 반면 부작용도 적지 않은데, 현재까지 보고된 주요 부작 용으로는 샘(gland) 기능의 증가로 땀 증가, 혈관 확장, 오 심이나 구토, 딸꾹질, 기관지 축소, 저혈압, 빈맥 등의 증 상들이 동반되는 것으로 알려져 있다(Aframian et al., 2007). 이처럼 장기간에 걸쳐 질환의 증상 개선 및 완화를 위해 투여되는 의약품의 부작용 발생을 감소시키기 위해 최근 에는 구강건조증 뿐만 아니라 다양한 질환을 대상으로 천 연약물에 대한 관심과 연구가 증가하고 있으며, 의약품의 효능에 준하는 약리적인 효능을 나타내면서 상대적으로 독성이 낮은 천연물들이 지속적으로 개발되고 있다(Braga et al., 2009).

본 연구에서는 보스웰리아(Boswellia Serrata)와 비타민 나무로 일컬어지는 산자나무(Hippophae rhamnoides L., seabuckthorn)를 이용하였고, 두 천연물질 모두 비타민이 풍부하게 함유된 대표적인 항산화 물질로 알려져 있으며 현재 건강보조 및 질환예방 목적으로 널리 사용되고 있다. 보스웰리아는 중등도 크기 정도의 분지 나무로 주요 성분 은 테르페노이드 및 보스웰릭산이며, 보스웰릭산은 소염 및 진통 효과를 나타내는 유효한 성분으로 알려져 있다 (Sailer et al., 1996). 보스웰릭산은 5-lipoxygenase (5-LO)의 활성을 저해시켜 생체 내에서 염증에 반응하는 물질 및 염증을 유발하는 물질인 interleukin 6 (IL-6), tumor necrosis factor-alpha (TNF- $\alpha)$ 등에 의한 cytokine 생성을 억제하게 되면서 염증성 질환이나 자기면역 질환에 효과적인 것으 로 보고되고 있다(Ammon, 2006; Siddiqui, 2011). 한편, 산자 나무는 보리수과(Elaeagnaceae)에 포함된 낙엽성 관목으로 비타민 C가 풍부하고 필수지방산의 일종인 $\alpha$-linoleic acid 및 linoleic acid가 다량 함유되어 있는 것으로 알려져 있는 데(Chen et al., 1990), 이는 화상을 비롯한 피부질환이나 상
처 치유제, 염증 및 궤양치료에 효과적인 것으로 알려져 있다(Yang et al., 2002). 또한 산자나무 잎의 추출물은 p38 mitogen-activated protein kinase (MAPK)를 비롯하여 NF-אB 활성억제를 통해 LPS에 의한 cyclooxygenase-2, TNF- $\alpha$, inducible nitric oxide synthase, nitric oxide (NO), IL-6 등의 단 백질 발현의 억제에 작용된다고 보고되었다(Jiang et al., 2017). 이상의 다양한 연구결과를 통해 두 천연물질은 공 통적으로 항산화 및 항염증 작용을 나타낸다는 것을 알 수 있다. 이러한 연구결과와 마찬가지로, 최근 본 연구의 선행 연구를 통하여 보스웰리아를 경구 투여한 뒤 $5 \%$ formalin을 실험동물의 안면부 피하 및 측두하악관절 내 로 주입한 실험에서 안면부 및 측두하악관절 염증성 통증 행위 반응 감소에 보스웰리아 투여가 효과적임을 입증하 였고(Lee et al., 2017), 동일한 실험모델에서 산자나무 추 출물을 경구 투여한 경우에도 유사한 통증경감효과를 확 인할 수 있었다(Kim et al., 2017).

이러한 선행 연구결과를 기초로 하여 구강건조증에 의 해 향상된 안면부 통증조절에서 두 가지의 천연물의 효 과를 확인하고자 실험을 고안하였고, 4-DAMP를 복강 내 로 주입하여 구강건조증을 유발시킨 실험동물을 대상으로 $5 \%$ formalin을 안면부에 주입하여 향상된 염증성 통증의 변화를 관찰하고, 단독 혹은 병용하여 경구 투여한 보스 웰리아와 산자나무가 구강건조증에 의해 향상된 안면부 통증조절에 효과적인지를 확인하고자 하였다.

\section{재료 및 방법}

\section{실험동물}

본 실험은 Sprague-Dawley계의 200 230 g의 생후 6 7 주령의 수컷 흰 쥐를 사용하였으며 효창사이언스(대구) 에서 공급받아 동의대학교 동물실험윤리위원회의 승인 (R2018-011)을 받아 진행하였다. 12시간 주.야 빛의 순환 주기를 주었으며 $23 \sim 26^{\circ} \mathrm{C}$ 온도를 일정하게 유지하였다. 또한 실험동물용 사료와 물을 자유롭게 공급하였으며 행 동적인 억압 등에 의한 스트레스를 최소화시켰고 의식이 있는 실험동물에 관한 통증연구학회의 윤리적 규정을 준 수하여 실험하였다.

\section{구강건조증 모델}

구강건조증을 유발하기 위하여 사용된 4-DAMP는 시그 마 알드리치사(Sigma-Aldrich Co., St. Luis, U.S.A)에서 구입 하여 사용하였다. 4-DAMP를 생리식염수에 희석하여 사 
용하였으며 $1 \mathrm{mg} / \mathrm{kg}$ 의 농도로 $1 \mathrm{~mL}$ 의 용량으로 실험동물 에 복강(intraperitoneal) 투여하였다. 투여 후 1 시간 경과 시점에서 $20 \%$ urethane $(0.5 \mathrm{~mL} / \mathrm{kg})$ 을 복강 투여하여 안정 위 상태로 마취시킨 다음 면구(cotton ball)를 구강 내 악하 선의 분비 도관부에 위치시키고 면구의 타액 흡수 전 후 의 무게 차이를 분비된 타액량으로 간주하여 30 분간 측 정한 결과 타액 분비량이 현저하게 감소된 것을 확인하여 구강건조증이 유발되었음을 확인하였다.

\section{시약준비}

보스웰리아 추출물(보스웰리아 추출물 열매 분말; Bioprex Labs Co., Ltd., Pune Maharashtra, India)은 15, $30 \mathrm{mg} / \mathrm{kg}$ 의 농도로 희석하여 $1 \mathrm{~mL}$ 의 용량으로 경구에 투여하였다. 산자나무 추출물(비타민나무 추출물 열매 분말; Shanghai Brichtolinternatilnal Co., Ltd., Tibet, China) 역시 150, $300 \mathrm{mg} /$ $\mathrm{kg}$ 의 농도로 희석하여 동일하게 $1 \mathrm{~mL}$ 의 용량으로 경구 투여하였다. 또한 두 약물의 병용 효과를 확인하기 위하 여 보스웰리아 $(15 \mathrm{mg})$ 와 산자나무 $(150 \mathrm{mg})$ 추출물을 함께 투여하였다. 각각의 약물을 주입한 후 30 분 경과한 뒤에 안면부 통증 유발을 위해 $5 \%$ formalin을 투여하였다.

\section{안면부 염증성 통증 유발}

구강안면부의 염증성 통증모델의 이전 실험방법을 참고 하여 동일하게 진행하였다(Lee et al., 2017). 구강건조증이 유발된 실험동물의 안면부 피하에 $5 \%$ formalin $(50 \mu \mathrm{L})$ 을 31 gauge의 인슐린 주사기를 사용하여 주입하였고, 약물 이 투여된 부위를 문지르거나 긁는 행위를 통증 지표로 간주하여 진행하였다. 주입 직후부터 총 45 분간 5 분단위 로 행위반응을 관찰하였으며, 통증행위 반응은 포르말린 주입으로 유발되는 말초감작 1 차 통증행위 반응 $(0 \sim 10$ 분, first phase)과 중추감작 2차 통증행위 반응(11 45분, second phase)으로 구분하여 평가하였으며(Lee et al., 2014), 실험이 진행되는 동안은 물과 사료 섭취를 제한하였다.

\section{통계분석}

실험결과는 IBM SPSS Statistic ver. 22.0 (IBM Co., Armonk, $\mathrm{NY}, \mathrm{USA}$ )을 이용하여 least significant difference 사후분석 법을 적용한 일원배치 분산분석을 하였고, Sigmaplot 2001 (SPSS Inc., Chicago, IL, USA)을 이용하여 그래프를 나타내 었다. 결과는 유의수준을 0.05 를 기준으로 하여 평균 \pm 표 준오차(standard error of the mean)로 표시하였다.

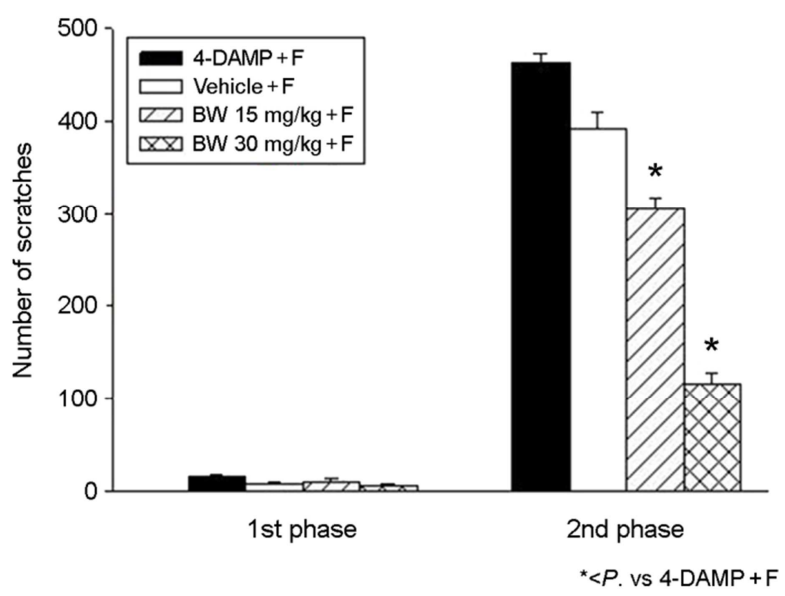

Fig. 1. The effect of the boswellia extract $(15,30 \mathrm{mg} / \mathrm{kg}$, BW) on behavioral responses following injection of formalin $(5 \%, 50 \mu \mathrm{L})$ into vibrissa pad. BW reduced behavioral responses during the second phase compared with $5 \%$ formalin-treated group. ${ }^{*} P<0.05$, vs $4-\mathrm{DAMP}+\mathrm{F}$

\section{결 과}

\section{구강건조증으로 유발된 안면부 염증성 통증모델에서 보 스웰리아 추출물의 효과}

4-DAMP를 복강 투여하여 구강건조증을 유발시킨 흰 쥐의 안면부 염증성 통증모델에서 보스웰리아 추출물의 경구 투여에 따른 통증행위 반응의 변화를 살펴보았다. 보 스웰리아 투여 시 1차 통증행위 반응은 4-DAMP + 포르 말린 주입군, 대조군(4-DAMP + veh + 포르말린 주입군) 그리고 약물 주입군 간의 뚜렷한 차이가 없었으나, 2 차 통증행위 반응에서는 포르말린 투여군에 비해 약물 주입 군(BW $15 \mathrm{mg} / \mathrm{kg}, 30 \mathrm{mg} / \mathrm{kg}$ )에서 통증행위 반응이 농도의존 적으로 유의하게 감소되었다 $(* P<0.05)$ (Fig. 1). 시간의 경 과에 따른 통증행위 반응의 변화는 BW $15 \mathrm{mg} / \mathrm{kg}$ 투여 시 에는 약물 주입 25분 경과 시점에서 가장 효과적으로 통 증행위 반응이 감소되었고, BW $30 \mathrm{mg} / \mathrm{kg}$ 투여군에서는 2차 통증행위 반응 대부분의 시점에 효과적이었다(Fig. 2). 이러한 결과를 통해 구강건조증으로 인하여 향상된 안면 부 염증성 통증조절에 보스웰리아가 효과가 있음을 확인 할 수 있었다.

\section{구강건조증으로 유발된 안면부 염증성 통증모델에서 산 자나무 추출물의 효과}

산자나무 추출물에 의한 통증경감효과는 보스웰리아와 마찬가지로 투여된 산자나무의 농도에 의존적으로 통증 


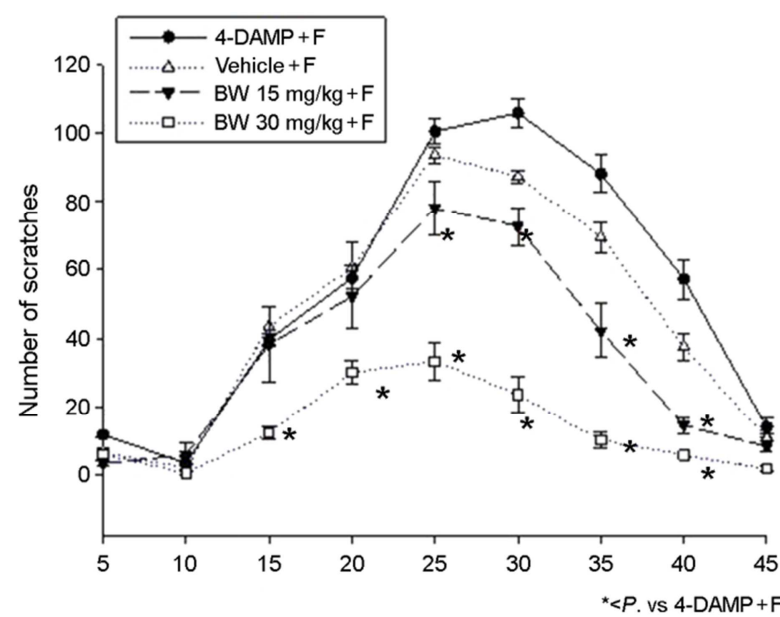

Fig. 2. Time response curve for the number of scratches responses following injection of formalin $(5 \%, 50 \mu \mathrm{L})$ into vibrissa pad 30 minutes after oral administration of boswellia extract. ${ }^{*} P<0.05$, vs 4-DAMP+F.

행위 반응의 감소를 확인할 수 있었다. 포르말린 주입 후 1 차 통증행위 반응에서는 약물 주입군 간의 유의한 차이 가 없었으나, 2차 통증행위 반응에서는 포르말린 주입군 에 비해 약물 주입군(SB $150 \mathrm{mg} / \mathrm{kg}, 300 \mathrm{mg} / \mathrm{kg}$ ) 모두 통증 행위 반응이 유의하게 감소되었다(*P<0.05) (Fig. 3). 이 러한 통증행위 반응을 시간의 경과에 따른 변화로 확인하 였을 때, SB $150 \mathrm{mg} / \mathrm{kg}$ 투여 시에는 포르말린 주입 25분 이후에 통증경감효과가 관찰된 반면에, $\mathrm{SB} 300 \mathrm{mg} / \mathrm{kg}$ 투 여군에서는 2 차 행위반응의 대부분의 시점에서 유의한 통증경감효과를 확인하였다(Fig. 4). 이러한 결과를 통해 산자나무도 보스웰리아와 마찬가지로 구강건조증으로 인 하여 향상된 안면부 염증성 통증조절에 효과적임을 알 수 있었다.

\section{안면부 염증성 통증모델에서 보스웰리아와 산자나무 추 출물의 병용 효과}

Fig. 5와 Fig. 6은 4-DAMP를 복강 투여하여 구강건조증 을 유발시킨 안면부 염증성 통증모델에서 저농도의 보스 웰리아와 산자나무 추출물의 병용 투여에 의한 통증행위 반응의 변화를 관찰한 결과 각각의 약물을 주입하고 관 찰한 통증경감의 효과에 비해 두 약물을 병용 투여했을 경우에 훨씬 효과적인 통증경감효과를 확인할 수 있었다

(Fig 4, 5).

이러한 결과를 통해 각각의 보스웰리아와 산자나무 추 출물의 투여는 구강건조증으로 인하여 발생된 안면부 염

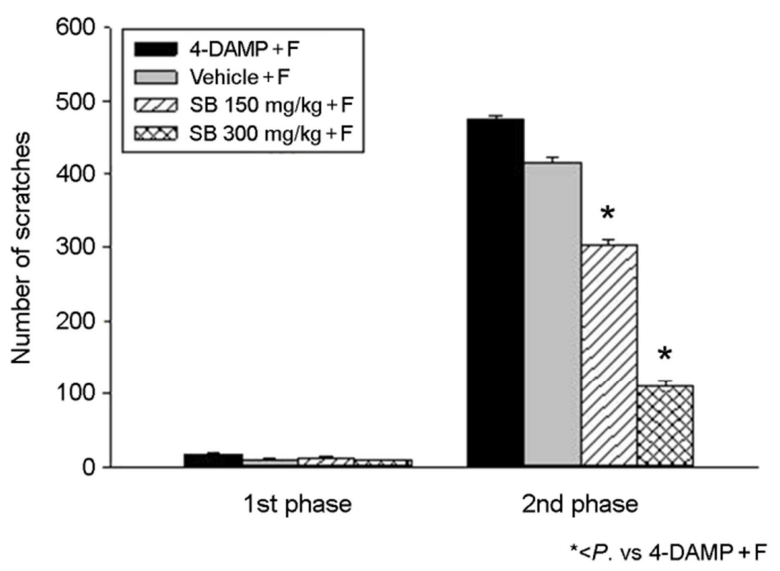

Fig. 3. The effect of the sea buckthorn extract $(150,300 \mathrm{mg} / \mathrm{kg}, \mathrm{SB})$ on behavioral responses following injection of formalin $(5 \%, 50 \mu \mathrm{L})$ into vibrissa pad. SB reduced behavioral responses during the second phase compared with $5 \%$ formalin-treated group. ${ }^{*} P<0.05$, vs 4 $\mathrm{DAMP}+\mathrm{F}$.

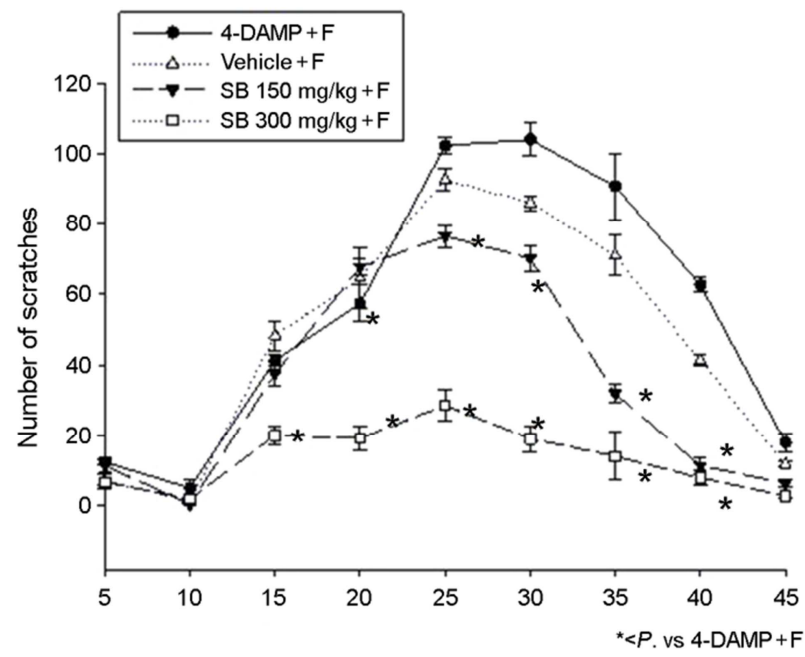

Fig. 4. Time response curve for the number of scratches responses following injection of formalin $(5 \%, 50 \mu \mathrm{L})$ into vibrissa pad 30 minutes after oral administration of sea buckthorn extract. ${ }^{*} P<0.05$, vs 4-DAMP+F.

증성 통증조절에 효과적이며, 저농도로 두 가지 물질을 병용 투여하였을 때 통증조절효과가 더 우수함을 알 수 있었다.

\section{고 찰}

구강안면부 통증(orofacial pain)은 구강 내 경조직 및 연 조직과 관련된 통증을 포함하는 것으로, 개구 및 저작 장 


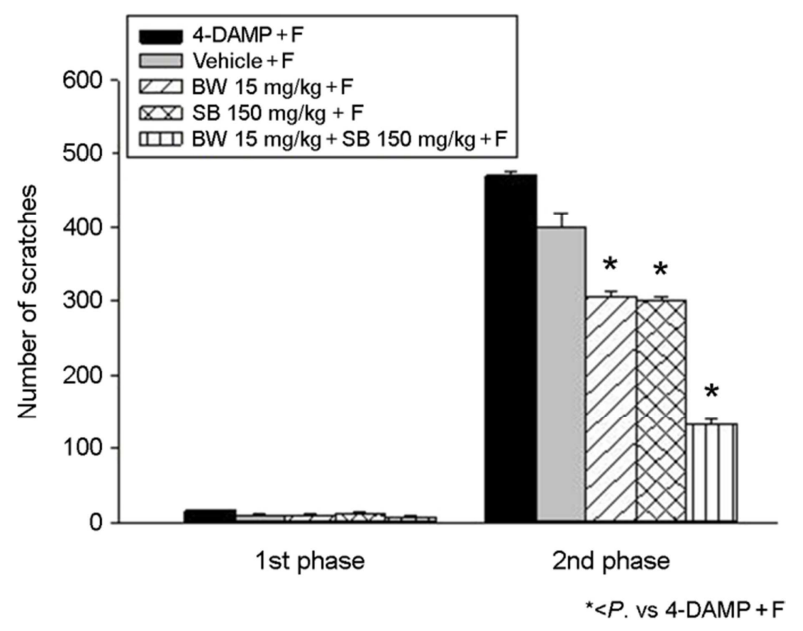

Fig. 5. 4-DAMP was administered intraperitoneally to the oral cavity, changes in the pain behavior response to oral administration of low concentrations of boswellia and sea buckthorn in the modified acute pain model. ${ }^{*} P<0.05$, vs $4-\mathrm{DAMP}+\mathrm{F}$.

애를 초래하며, 측두하악관절 장애(temporomandibular disorder, TMD)나 삼차신경통과 같은 신경병증성 통증 뿐 아 니라 두통이나 근골격성, 신경계 등의 동통으로 나타나는 것으로 알려져 있다(Rhodus, 1988). 이러한 치료를 위하여 대개 비스테로이드성 약물(nonsteroidal antiinflammatory drug, NSAID)을 처방 받아 복용하는데, 이 약물은 뛰어난 진통 효과를 기대할 수 있지만 위장관 독성이나 장기간 복용으 로 인한 혈전증 등의 부작용이 발생할 수 있어 복용에 주 의가 필요하다(Kim and Lee, 2015). 이러한 부작용을 최소 화하기 위해 최근에는 비교적 부작용이 적은 천연물질에 대한 관심이 증가하고 있는 실정이다.

본 연구에서는 최근 항산화 및 항염증 등 다양한 효능 으로 주목받고 있는 보스웰리아 및 산자나무 추출물을 구 강건조증에 의해 유발된 안면부 염증성 통증모델에서 역 할을 규명하고자 하였다. 먼저, 보스웰리아 및 산자나무 추출물을 경구 투여하여 나타나는 안면부 통증에 미치는 영향을 확인한 결과, 대조군에 비해 보스웰리아 및 산자 나무 추출물 투여군에서 농도의존적으로 통증이 감소하였 다. 이러한 결과는 최근 보고되고 있는 천연물에 의한 안 면부 통증조절 연구결과들과 유사한 것으로, 포르말린으 로 유도한 흰 쥐의 안면부 통증모델에서 커피생콩 추출물 을 $30,60 \mathrm{mg} / \mathrm{mL}$ 의 농도로 투여하였을 때 농도의존적으로 통증행위 반응이 유의하게 감소된다는 것을 보고하였고 (Lee et al., 2018), 홍삼 및 흑삼 추출물이 간과 신장에 부 작용이 발생되지 않으면서 안면부 통증모델에서 통증반

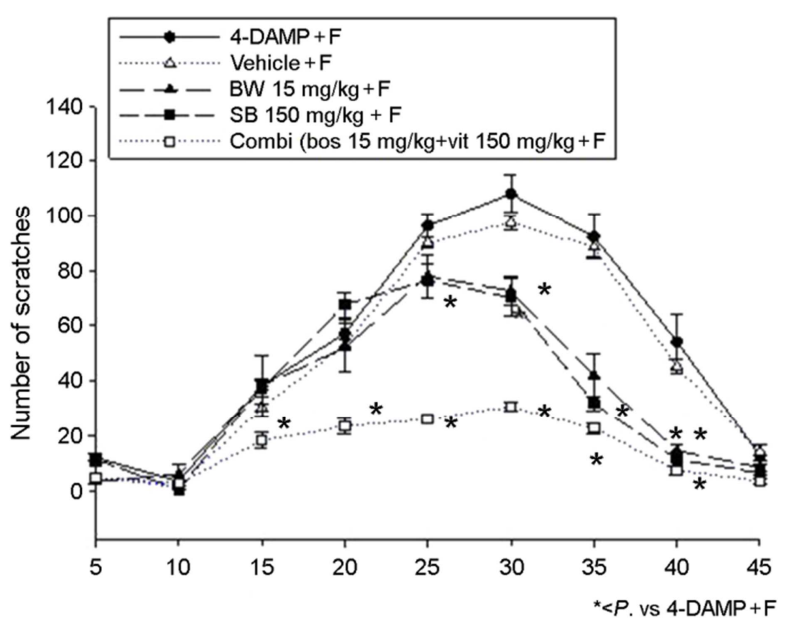

Fig. 6. BW $15 \mathrm{mg} / \mathrm{kg}$ and SB $150 \mathrm{mg} / \mathrm{kg}$ were administered, the response was found to be effective at $25 \sim 40$ minutes after administration of $\mathrm{BW}+\mathrm{SB}$, The orofacial pain relief effect was higher at the time of the minute. ${ }^{*} P<0.05$, vs $4-\mathrm{DAMP}+\mathrm{F}$.

응을 유의하게 감소시켰으며, 이는 $\operatorname{Nrf} 2$ 의 발현의 조절을 통해서라고 보고하였다(Lee et al., 2017). 이러한 결과들을 바탕으로 천연물은 안면부 통증의 직접적인 조절에 관한 연구 뿐만 아니라, 구강의 다양한 질병에서 유의한 역할 을 한다는 보고가 꾸준히 발표되고 있다. 최근 한 연구에 따르면, 성인을 대상으로 씀바귀 및 갈근 추출물의 투여 후 타액분비효과를 비교한 연구에서, 증류수를 머금고 있 을 때 타액 분비는 $0.41 \pm 0.021 \mathrm{~mL} / \mathrm{min}$, 씀바귀 추출물 투 여 시에는 $20 \%$ 정도 증가한 $0.49 \pm 0.029 \mathrm{~mL} / \mathrm{min}$ 이였으며 갈근 추출물은 $0.54 \pm 0.014 \mathrm{~mL} / \mathrm{min}$ 으로 약 $32 \%$ 가 증가한 다는 것이 보고되었다(Jung et al., 2018). 구강건조증은 인 구의 증가와 함께 유병률이 급증하고 있는 구강의 주요 질환으로 구강의 건조감은 치아우식증이나 치주질환을 가 속화시키는 원인이 되고, 본 연구에서처럼 안면부의 통증 을 향상시키는 기저질환으로 작용할 수도 있다. Fox (1987) 의 연구에 의하면 구강건조증을 호소하는 환자군에서 타 액 분비의 감소로 인한 기능 저하로 이차적 지환인 치아 우식이 발병되는 비율이 높다고 발표하였다. 또한 대조군 에 비하여 구강건조감을 호소하는 군에서 소화불량, 불면 증, 위장염 등과 같은 질환을 호소하는 비율이 많았다는 $\mathrm{Oh}$ 등의 (2001) 연구를 통하여 구강건조증과 통증이 관련 되어 있음을 확인할 수 있었다. 따라서, 타액의 유출량, 점 도 및 $\mathrm{pH}$ 등의 조절을 위해 다양한 연구가 이루어져야 할 것이고, 지속적인 효과를 나타내기 위해 장기간 사용 함에 있어서 비교적 부작용이 적은 천연물이 연구대상이 
되어야 한다고 생각된다.

본 연구에서 사용된 천연물인 보스웰리아의 효능은 11keto-b-boswellic acid (KBA)와 acetyl-11-keto-b-boswellic acid (AKBA)을 포함한 선택적 5-lipoxygenase (5-LO)의 조절 에 의한 것으로 알려져 있는데, Kiela 등의 연구에 의하면 $\mathrm{KBA}$ 또는 $\mathrm{AKBA}$ 가 증가하면 염증성 질환의 발생 및 진 행에서 사이토카인의 조절에 관여하는 인자인 The nuclear transcription factor (NF-kB)의 발현이 감소된다는 것이 보고 되었다(Abdel-Tawab et al., 2011). 또한 위장 및 심혈관 계 통의 통증모델에서 비스테로이드성 항염증제(NSAIDs)에 비하여 보스웰리아의 통증 저항력이 더 효과적이라는 연 구결과(Prabhavathi et al., 2014)도 이러한 보스웰리아의 통 증조절제로써의 가능성을 입증하는 것으로 보여진다. 본 실험에서도 보스웰리아의 주입은 구강건조증에 의해 유발 된 안면부 염증성 통증경감에 효과적인 것을 확인하였고, 이러한 결과를 바탕으로 보스웰리아가 염증질환이나 통증 의 발생 및 조절에 효과적인 약물로 적용될 수 있음을 시 사한다. 이와 마찬가지로, 산자나무 추출물 역시 염증 및 통증조절에 효과적이라는 것을 입증한 다양한 연구결과들 이 보고되었다. 산자나무의 생화학적 구성에 관한 연구에 따르면 산자나무가 함유하고 있는 다양한 종류의 비타민, 미량 원소, 아미노산 및 다양한 생리 활성 물질이 다용도 의 약리학적 활동을 담당하고 있으며, 산자나무 추출물은 감염을 방지하고 항산화 물질이 풍부하여 염증 상태를 개 선시키는 것으로 보고되었다(Xing et al., 2002). 또한, 산자 나무는 linoleic과 linolenic acid의 함량이 높고 항산화 특 성에 상응하는 카로티노이드, flavonoids 및 phytosterols를 포함한 높은 pyhtochemical material을 다량으로 함유하고 있어서 감소된 glutathione (GSH)과 glutathione peroxidase $(\mathrm{GPx})$ 와 같은 세포 내 항산화 물질을 회복시켜 ROS/free 의 라디칼 생산의 억제한다고 알려져 있다(Geetha et al., 2003). 마찬가지로, Richa 등 (2013)의 연구에 의하면, 중형 잡종 성견 20마리를 대상으로 덱사메타손(dexamethasone) $1 \mathrm{mg} / \mathrm{kg}$ 을 투여하여 위궤양을 유발한 모델에서 산자나무 추출물 투여에 의한 유의한 통증경감효과가 입증되었다. 이와 더불어 식욕의 현저한 개선이 관찰되었으며, 대변 잠 혈 검사에서도 양성이었으며 혈청 생화학 검사는 연구 전 반에 걸쳐 정상적인 생리학적 한계 내에서 유지되었다. 또 다른 연구에 의하면, 실험동물의 피부조직에 상처를 내 어 산자나무 잎 추출물을 해당 조직에 도포하면 육아조직 의 항산화 수준이 증가되어 상처치유효과가 나타난다는 것이 보고되었다(Gupta et al., 2005). 이를 결과들과 마찬가
지로 본 연구에서도 산자나무 추출물이 구강건조증에 의 해 향상된 안면부 염증성 통증을 유의하게 조절함을 밝 혔고, 이러한 결과는 산자나무의 통증 및 염증조절제로서 의 가능성을 보여주는 것으로 생각된다.

본 연구에서 흥미로운 점은, 두 가지의 약물을 저농도 로 병용했을 때 각각의 단독 투여 효과에 비해 훨씬 유 의한 통증경감효과를 확인한 것이다. 약물의 효과를 극대 화하기 위해 고농도의 단독 주입은 조직과 신경의 손상을 유발하거나 오히려 약효의 반전을 나타내는 경우도 있다. 최근에는 울트라셋정과 같은 약리작용 기전이 명확한 약 물의 혼합제제가 개발되는 등 부작용의 범위를 줄이면서 유효한 약효를 확보하려는 연구 및 개발이 증가되고 있다. 실험적으로 보고된 한 예로, 신경 병증성 통증 동물모델 을 이용하여 gabapentin과 milnacipran의 병용 투여는 각각 의 단독 투여에 의해 효과적으로 증가된 통증경감효과를 나타내었음이 보고되었다. 일부 연구에서는 유효한 화학 약제와 천연물의 병용을 시도하여 좋은 연구결과를 보여 주기도 하는데, 최근에 미역순나무의 주요 성분인 트립 톨리드(triptolide)와 nitric oxide (NO)의 합성 억제제인 Nnitro-L-arginine Methyl Ester의 병용 투여가 흰 쥐의 측두 하악관절 통증조절에 효과적이라는 것이 확인되었다(Kim and Lee, 2015). 이러한 결과와 유사하게, 본 연구에서도 두 가지 천연물의 병용 투여에 의해 안면부 염증성 통증 이 효과적으로 감소되는 것을 확인하였다. 물론 향 후 천 연물의 작용기전에 관한 구체적인 연구가 추가되어야 하 며, 지속적인 투여를 위해서는 안정적인 적용범위를 확보 하는 것이 필수적이라고 생각된다.

이상의 연구결과를 종합해보면, 보스웰리아와 산자나무 추출물은 구강건조증으로 인하여 향상된 안면부 염증성 통증을 유의하게 감소시켰으며, 두 약물의 저농도 병용 투여 시에는 각각의 단독 투여에 비해 더욱 효과적으로 통증조절효과를 나타내었다. 이러한 결과들을 통해 안면 부 염증성 통증조절을 위한 약물로써 보스웰리아 및 산자 나무 추출물이 치료제로 제시될 수 있으며, 약물의 병용 투여에 의한 상호작용은 약리학적 가치를 더욱 증가시킬 수 있을 것으로 사료된다.

\section{ACKNOWLEDGEMENT}

This work was supported by the National Research Foundation of Korea (NRF) grant funded by the Korea government (MSIT) (NRF-2017R1C1B5076722). 


\section{CONFLICT OF INTEREST}

The authors declare no conflicts of interest.

\section{REFERENCES}

Abdel-Tawab M, Werz O, Schubert-Zsilavecz M. Boswellia serrata: an overall assessment of in vitro, preclinical, pharmacokinetic and clinical data. Clin Pharmacokinet. 2011. 50: 349-369.

Aframian DJ, Helcer M, Livni D, Robinson SD, Markitziu A, Nadler C. Pilocarpine treatment in a mixed cohort of xerostomic patients. Oral Dis. 2007. 13: 88-92.

Ammon HP. Boswellic acids in chronic inflammatory diseases. Planta Med. 2006. 72: 1100-1116.

Braga MA, Tarzia O, Bergamaschi CC, Santos FA, Andrade ED, Groppo FC. Comparison of the effects of pilocarpine and cevimeline on salivary flow. Int J Dent Hyg. 2009. 7: 126-130.

Chen Y, Jiang Z, Qin W, Ni M, Li X, He Y. Chemical composition and characteristics of seabuckthorn fruit and its oil. Chem Ind Forest Prod. 1990. 10: 163-175.

Choi JS, Lim JY. Diagnosis and treatment of xerostomia. Korean Journal of Otorhinolaryngology-Head and Neck Surgery. 2016. 59: 424-429.

Fox PC, Busch KA, Baum BJ. Subjective reports of xerostomia and objective measures of salivary gland performance. J Am Dent Assoc. 1987. 115 501-584.

Geetha S, Sai Ram M, Mongia SS, Singh V, Ilavazhagan G, Sawhney RC. Evalution of antioxidant activity of leag extract of Seabuckhorn on chromium induced oxidative stress in albino rats. J Ethnopharmacology. 2003. 87: 247-251.

Gerdin EW, Einarson S, Jonsson M, Aronsson K, Johansson I. Impact of dry mouth conditions on oral health related quality of life in older people. Gerodontol. 2005. 22: 219-226.

Gupta A, Kumar R, Pal K, Banerjee PK, Sawhney RC. A preclinical study of the effects of seabuckthorn (Hippophae rhamnoides

L.) leaf extract on cutaneous wound healing in albino rats. Int J Low Extrem Wounds. 2005. 4: 88-92.

Jang HJ, Baik SH, Kim AJ, Jung SH, Kim OS, Kim SH. The effect of xerostomia on perceived oral health among elderly people wearing dentures. The Journal of the Korean Academy of Dental Health. 2006. 30: 438-446.

Jung NH, Chang JH, Hong JY, Kweon DK, Han JA. Comparison of extract components and saliva secretion of ixeridium dentatum and pueraria iobata Ohwi. Korean J Food Cook Sci. 2018. 34: 358-365.
Jiang F, Guan H, Liu D, Wu X, Fan M, Han J. Flavonoids from sea buckthorn inhibit the lipopolysaccharide-induced inflammatory response in RAW264.7 macrophages through the MAPK and NF-кB pathways. Food Funct. 2017. 8: 1313-1322.

Kim JH, Park JH, Kwon JS, Ahn HJ. Effect of Pilocarpine mouthwash on xerostomia. Korean journal of oral medicine. 2011 36: 21-24.

Kim YK, Lee MK. Analgesic effects of triptolide and N-nitro-Larginine methyl ester in rat's temporomandibular joint pain model. J Korean Soc Dent Hyg. 2015. 15: 800-806.

Kim YK, Choi JH, Kim HJ, Yoon HS, Hyun KY, Lee MK. Analgesic Effect of hippophae rhamnoides extract in orofacial pain in rats. J Dent Hyg Sci. 2017. 17: 495-500.

Lee HJ, Kim YK, Choi JH, Lee JH, Kim HJ, Seong MG, Lee MK. Effects of red or black ginseng extract in a rat model of inflammatory temporomandibular joint pain. J Dent Hyg Sci. 2017. 17: 65-72.

Lee JS, Lee MK, Kim YK, Kim KE, Hyun KY. Attenuant effects of hovenia dulcis extract on inflammatory orifacial pain in rats. J Korea Acad Industr Coop Soc. 2014. 15: 5088-5094.

Lee MK, Kim HJ, Park MK. Regulation effects of orofacial pain by green coffee bean extracts in rats. J Korean Soc Oral Health Sci. 2018. 6: 53-58.

Napenas JJ, Brennan MT, Fox PC. Diagnosis and treatment of xerostomia (dry mouth). Odontology. 2009. 97: 76-83.

Oh JK, Kim JY, Kho HS. A study on the clinical characteristics of patients with dry mouth. Journal of Oral Medicine and Pain 2001. 26: 331-343.

Prabhavathi K, Chandra US, Soanker R, Rani PU. A randomized, double blind, placebo controlled, cross over study to evaluate the analgesic activity of Boswellia serrata in healthy volunteers using mechanical pain model. Indian J Pharmacol. 2014. 46: 475-479.

Rhodus NL. Xerostomia and the geriatric patient. Dentistry. 1988. 8: 12-17.

Richa D, Tyagi SP, Amit K. Efficacy of Seabuckthorn (Hippophae rhamnoides) Oil vis-a-vis Other Standard Drugs for Management of Gastric Ulceration and Erosions in Dogs. Vet Med Int. 2013. 2013: 176848

Sailer ER, Subramanian LR, Rall B, Hoernlein RF, Ammon HP, Safayhi H. Acetyl-11-keto-beta-boswellic acid (AKBA): structure requirements for binding and 5-lipoxygenase inhibitory activity. Br J Pharmacol. 1996. 117: 615-618.

Siddiqui MZ. Boswellia serrata, a potential antiinflammatory agent: an overview. Indian J Pharm Sci. 2011. 73: 255-261. 
Thomson WM, Lawrence HP, Broadbent JM, Poulton R. The impact of xerostomia on oral-health-related quality of life among younger adults. Health Qual Life Outcomes. 2006. 86: 1-7.

Xing J, Yang B, Dong Y, Wang B, Wang J, Kallio HP. Effects of seabuckthorn (Hippophae rhamnoides L.) seed and pulp oils on experimental models of gastric ulcer in rats. Fitoterapia. 2002. 73: 644-650.

Yang ZG, Li HR, Wang LY. Triterpenoids from hippophae rhamnoides L. and their nitric oxide productioninhibitory and DPPH radical-scavenging activities. Chem Pharm Bull. 2002. 55: $15-18$.
Yasuko I, Takafumi E, Mariusz TS, Hajime I. Acetylcholine acts on M3 muscarinic receptors and induces the translocation of aquaporin5 water channel via cytosolic $\mathrm{Ca}^{2+}$ elevation in rat parotid glands. Biochimica et Bioptzvsiea Acta. 1998. 245: 835-840.

https://doi.org/10.15616/BSL.2019.25.2.131

Cite this article as: Choi JH, Kim TH, Lee MK. Effects of Sea Buckthorn and Boswellia Extracts in Inflammatory Orofacial Pain by Xerostomia in Rats. Biomedical Science Letters. 2019. 25: 131-138. 